Magdalena Hoły-Łuczaj

Wyższa Szkoła Informatyki i Zarządzania, Rzeszów

e-mail: mholy@wsiz.edu.pl

ORCID: 0000-0001-5860-3638

\title{
Kształtowalność - Arystotelesowska afektywność i brakujący wymiar bycia u Heideggera
}

\section{Wprowadzenie}

„Każdy myśliciel myśli tylko jedną myśl”1. To przekonanie wyrażone przez Martina Heideggera można interpretować, cóż za zaskoczenie, bardzo różnie. Można odnieść je do odnalezienia tematu - zagadnienia, problemu, wątku - który organizuje cały wysiłek konceptualny, nadając mu określoną spójność, kierunek i logikę. Jedna jedyna myśl pozwala wówczas na niezwykłą koncentrację, umożliwiającą zarówno odkrycie nowych sensów, jak i zrewidowanie utartych wyobrażeń. Można jednak też postrzegać jedną jedyną myśl jako idée fixe, która swoim natręctwem zamyka myślenie na inne kwestie, konteksty, perspektywy. Często granica między tymi dwoma potencjalnymi dominantami myślenia jest płynna - współwystępują właściwie one ze sobą. Przykładem tego może być koncepcja różnicy ontologicznej samego Heideggera. Namysł nad ujawnianiem się bycia w jego różnicy z bytem umożliwił mu przepraco-

1 Martin Heidegger, Nietzsche, t. 1, przeł. Cezary Wodziński i in. (Warszawa: WN PWN, 1999), 475. Jak bardzo potwierdza się to w przypadku Heideggera - jego własnego projektu i interpretacji innych filozofów - pokazują m.in. Cezary Wodziński, Heidegger i problem zła (Gdańsk słowo/obraz terytoria 2007), 303; Jolanta Żelazna, „The «Essential Thought» of Martin Heidegger as a Continuation of Nietzsche's Philosophy of Time", Studia Filozoficzne 218, 1 (1984): 69-84. 
wanie wielu tradycyjnych kategorii filozoficznych i stworzenie szeroko zakrojonego, złożonego projektu filozoficznego. Równocześnie wydaje się, że koncentracja na dynamizmie różnicy ontologicznej immunizowała Heideggerowskie myślenie na uwzględnienie fenomenu wzajemnego oddziaływania na siebie bytów, które je zmienia, wpływając na ich kondycję, co wydaje się istotne dla uchwycenia sensu bycia.

To pominięcie można pokazać na przykładzie Heideggerowskiej interpretacji ujęcia tego zjawiska przez Arystotelesa ${ }^{2}$, który opisał je w Metafizyce i w mniej znanym dziele O powstaniu i niszczeniu. Diagnoza postawiona przez Stagirytę dotyczy tego, jak przemiany w bytach, w tym te prowadzące do ich zniszczenia, ugruntowane są w afektywności, czyli

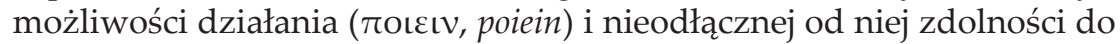
ulegania wpływowi ( $\pi \alpha \sigma \chi \varepsilon เ v$, paschein) tego działania.

Heidegger odczytuje owo rozpoznanie jako odnoszące się do mechanizmów od-krywania się bycia, które nie jest rządzone prawami ludzkiej subiektywności. Ta interpretacja zarówno intryguje, jak i ujawnia pewną lukę w ontologii Heideggera, dotyczącą braku ujęcia kwestii wzajemnego odziaływania na siebie bytów i przełożenia tego na ich ontologiczny status, na czym skupia się Arystoteles.

Zasadnicze pytanie dotyczy tego, czy tę lukę można uzupełnić. $\mathrm{W}$ artykule pokażę, że jest to możliwe, ponieważ filozofia Heideggera jest projektem otwartym, który oferuje grunt dla jego dalszego rozwinięcia. Dlatego Arystotelesowska jukstapozycja działania i doznawania nie służy tu tylko zilustrowaniu pewnego braku w ontologii Heideggera, ale stanowi przede wszystkim inspirację, aby spróbować wpisać w nią koncepcję „,kształtowalności”. Będzie to wymiar odsłaniania się bycia związany z nieustannym oddziaływaniem przez byty i doznawaniem jego skutków. Pozwoli to pokazać, że bycie rozumiane jako odkrywanie swoistości danego bytu (bycie-tym-właśnie) ujawnia się nie tylko poprzez wymiary wskazane przez Heideggera, ale także w śladach - przekształceniach - będących znakiem ulegania zmianom spowodowanym przez oddziaływanie na nie innych bytów ${ }^{3}$.

W związku z zarysowanym powyżej zamiarem plan artykułu wygląda następująco. W części pierwszej postawiono pytanie o ontologiczną impregnację bytów w filozofii Heideggera. Część druga zawiera

2 Odniesienie się do niej jest istotne, ponieważ, jak twierdzi Wawrzyniec Rymkiewicz, „dzieło Heideggera wyłania się z komentarza do Arystotelesa” (Wawrzyniec Rymkiewicz, Formy istnienia. Heidegger wedtug Arystotelesa (Warszawa: Fundacja Augusta hr. Cieszkowskiego, 2015), 15, 93).

${ }_{3}$ Powyższa problematyka została wstępnie przez mnie przedstawiona w artykułach: „Kształtowalność. Próba rewizji struktur Heideggerowskiego bycia w czasach antropocenu”, Analiza i Egzystencja 48 (2019); "Shapeability. Revisiting Heidegger's Concept of Being in the Anthropocene", Cosmos and History: The Journal of Natural and Social Philosophy 15, 1 (2019). 
przedstawienie Arystotelesowskiego ujęcia zjawiska działania-doznawania, jego Heideggerowską interpretację oraz krytykę tej interpretacji. W części trzeciej następuje rozwinięcie koncepcji „kształtowalności” jako wymiaru odsłaniania się bycia, przy jednoczesnym dokonaniu rewizji relacji czasowości i światowości. W części czwartej omówiono problem bycia-ku-śmierci w odniesieniu do zagadnienia kształtowalności.

\section{Ontologiczna impregnacja?}

Czy Heidegger - myśliciel problematyki nieobecności, zmieniającego się sensu bycia $\mathrm{w}$ dziejach metafizyki, napięcia między skrytością a nieskrytością - stworzył dynamiczny obraz bytów? Odpowiedź na to pytanie, jak zazwyczaj bywa w przypadku tego filozofa, jest złożona.

Według Heideggera bycie nie jest żadnym elementem bytu ani samo nie jest bytem, ani nie jest takie jak byt. Bycie, co Heidegger stara się wyeksplikować w ciągu całej swojej drogi myślowej, jest związane z ruchem odsłaniania bytu w jego swoistości. Przyjęcie przez nas takiej formuły jest oczywiście w znacznej mierze prowizoryczne i nie sprawia, że zagadka bycia zostaje rozwiązana. Same składające się na nią zagadnienia - odsłanianie i swoistość - są wieloznaczne, nie mówiąc o ich złączeniu. Niemniej wydaje się, że to wokół nich krąży myślenie bycia u Heideggera. Gdy przyglądamy się Heideggerowskiej terminologii, okazuje się, że jej znacząca część jest oparta na przymiotniku eigen, który tłumaczymy jako „własny", "właściwy” "swoisty”, "osobliwy”. Widać to już we wczesnych pracach, w których spotykamy m.in. pojęcia: eigenste (najbardziej własny), eigentlich (właściwy, prawdziwy, autentyczny), Eigentlichkeit (właściwość, autentyczność) ${ }^{4}$. Symbolem zwrotu, jaki ma miejsce w późniejszym okresie, są zaś terminy er-eignen (wy-darzać, przy-swajać) oraz Er-eignis (wy-darzanie, przy-swojenie) ${ }^{5}$.

Przekonanie, że bycie ujawnia się - wychodzi ze skrytości - zza bytu, odkrywając w ten sposób byt w tym, co dla niego najbardziej własne, odchodzi od tradycyjnego schematu metafizycznego, jakim jest opozycja istoty $\mathrm{i}$ istnienia. Heidegger nie akceptuje ich prostego przeciwstawienia.

${ }^{4}$ Zob. "Słownik terminologiczny”, w: Martin Heidegger, Bycie $i$ czas, przeł. Bogdn Baran (Warszawa: WN PWN 2005), 550.

${ }_{5}$ Zob. Janusz Mizera, W strone filozofii niemetafizycznej. Martina Heideggera droga do innego myślenia, (Kraków: Wyd. UJ 2006), 73; Wodziński, Heidegger i problem $z \nmid a, 338$. W ten semantyczny krąg „swoistości” wpisują się również pojęcia istoczenia (Wesen) i wy-istaczania (An-wesen) jako inne z określeń bycia (Sein), które odnoszą się do odsłaniania tego, co swoiste bytu - jego istotowości (Anwesenheit), co dobrze wydobywa w swym przekładzie Wawrzyniec Rymkiewicz, zob. Martin Heidegger, Podstawowe zagadnienia filozofii, przeł. Wawrzyniec Rymkiewicz (Warszawa: Fundacja hr. Cieszkowskiego 2017), 64. 
To główny powód sprzeciwu wobec Jeana-Paula Sartre’a, od którego egzystencjalizmu Heidegger odciął się w Liście o "humanizmie" (1946), tłumacząc, że różnica między - gdyby chcieć operować klasyczną terminologią - istotą (esencją) i istnieniem/byciem (egzystencją) przynależy do korpusu tradycyjnej metafizyki i Sartre' owskie odwrócenie „egzystencja poprzedza esencję" nie wychodzi poza jej logikę $e^{6}$. Heidegger twierdzi raczej, że ek-sistencja polega na od-słanianiu istoty: wy-chodzeniu ku jej jawności ${ }^{7}$.

To Heideggerowskie dążenie - przybierające na sile w późniejszych pracach - do myślenia poza dychotomią istoty i istnienia może jednak skutkować nie tylko tym, że ich relacja nabiera pewnej nieczytelności ${ }^{8}$, ale nawet pytaniem, czy nie mamy tu do czynienia ze specyficznym esencjalizmem czy też ontologiczną impregnacją bytów. Możemy je rozważyć, odnosząc się do Heideggerowskiego ujęcia różnicy ontologicznej - odmienności tego, co ontyczne (dotyczące bytu) i ontologiczne (dotyczące bycia) - w kontekście problemu światowości.

Heidegger wprowadza ideę światowości (Weltlichkeit) jako wymiaru odsłaniania się bycia na przykładzie narzędzia. Mówi, że gdy wymieniamy określone cechy pióra i kartki papieru leżących na stole, takie jak bycie drewnianym, białą itp., dokonujemy opisu ontycznego. Staje się on ontologiczny wtedy, gdy zwracamy uwagę na to, jak te cechy umożliwiają rzeczom wzajemne ujawnienie ich swoistości - „odniesienie" do określonej funkcjị. Aby bowiem pokazać, że długopis jest „do pisania”, trzeba uwidocznić to, że pojedyncze narzędzie jest abstrakcją i faktycznie mamy zawsze do czynienia z określonym „związkiem narzędziowym"10. Jeśli bowiem długopis ma odkryć się jako rzecz do pisania, wymaga to kartki (lub jakiejkolwiek innej rzeczy), na której coś mogłoby

${ }^{6}$ Martin Heidegger, List o "humanizmie”, przeł. Józef Tischner, w: Martin Heidegger, Znaki drogi (Warszawa: Aletheia 1999), 283; por. Magdalena Hoły-Łuczaj, „Kształtowalność. Próba rewizji struktur Heideggerowskiego bycia w czasach antropocenu", Analiza i Egzystencja 48: 71. Pamiętajmy, że to tak bezpośrednie odcięcie się od egzystencjalizmu ma miejsce bez mała dwadzieścia lat po publikacji Bycia $i$ czasu. Podstawowym kontekstem dla tej krytyki jest nietrafne odczytanie - co staje się widoczne z perspektywy późniejszych prac Heideggera - znaczenia roli człowieka w określaniu sensu bycia. Po zwrocie, który zachodził w połowie lat trzydziestych, Heidegger podkreślał, że choć człowiek jest niezbędny w odkrywaniu bycia, to nie jest jego źródłem - wręcz przeciwnie, to bycie ugruntowuje status człowieka jako jest-estwa/jawno-bycia (Da-sein). Heidegger w ten sposób jednoznacznie odchodził od antropocentrycznego nastawienia europejskiej filozofii, które według niego ciążyło też nad ideą humanizmu oraz było obecne w egzystencjalizmie.

7 Heidegger, List o "humanizmie", 287-288.

8 Rymkiewicz, Formy istnienia, 327-339.

9 Heidegger, Bycie i czas, 107-108.

${ }_{10}$ Martin Heidegger, Podstawowe problemy fenomenologii, przeł. Bogdan Baran (Warszawa: Aletheia 2009), 176. 
zostać zanotowane, by być widoczne. Równocześnie pisanie wymaga stabilnego oparcia itd.

Poprzez światowość zostaje zatem odsłonięty sens (jeśli przyjęlibyśmy perspektywę wczesnej filozofii Heideggera) lub swoistość bytu jego bycie. Bycie długopisu ujawnia się poprzez funkcjonowanie (pisanie) w połączeniu z innymi rzeczami. Mówiąc inaczej, byty tylko we wzajemnym powiązaniu mogą odkryć (swoje) bycie. Idea świata jako sieci odniesień nie powinna być sprowadzana do tezy, że każdy byt potrzebuje tła lub kontekstu, by być zrozumiałym. Koncepcja światowości pokazuje, że relacyjność bytów - ich ontologiczna kolektywność - jest nieredukowalnym momentem odsłaniania bycia.

Równocześnie jednak obraz relacji między bytami w ontologii Heideggera wydaje się istotnie zubożony. Jego analizy są niedookreślone w kategoriach ich interakcji czy też oddziaływania. Problemem jest pominięcie nie tylko tego, jak byty się zmieniaja, ale tego, że się zmieniają. Heidegger pomija to, że byty wskutek funkcjonowania w zetknięciu $\mathrm{z}$ innymi bytami ulegają znaczącym przemianom - długopis staje się wypisany, kartka zapisana - co wpływa na ich swoistość jako jednostek. Innymi słowy, w ujęciu Heideggera byty zachowują daleko idącą wobec siebie rezerwę: wspólnie odsłaniają swoistość, ale raczej będąc obok siebie, pozostając niewrażliwe na wzajemne oddziaływanie, co jest też częstym zarzutem stawianym koncepcji współ-bycia (Mitsein) jednostek ludzkich ${ }^{11}$.

Oczywiście można stwierdzić, że możliwość wypisania i zapisania są właściwe dla samej kartki czy długopisu - stanowią ich własne, niejako wewnętrzne możliwości ${ }^{12}$ - i w tym znaczeniu interakcje między nimi a pozostałymi bytami nie wpływają na ich bycie. Należy mieć jednak na uwadze to, że te możliwości nie ujawniłyby się, gdy nie interakcje między tymi bytami. Ponadto te interakcje mogą nawet doprowadzić do możliwości niemożliwości funkcjonowania bytów, o których tu mowa. $\mathrm{Z}$ tego właśnie powodu utrzymuję, że oddziaływanie między bytami,

11 Współbycie pozostało nierozwiniętym wątkiem w filozofii Heideggera, który w późniejszym okresie porzucił tę koncepcję. Jednak nawet jej ujęcie z Bycia $i$ czasu było dla wielu krytyków niesatysfakcjonujące, jak choćby dla Emmanuela Levinasa, który stwierdził, że powinno być ono raczej nazwane współ-maszerowaniem (zusammenmarschieren), ponieważ nie uchwytuje bezpośredniości i intensywności ludzkich kontaktów.

12 Por. Martin Heidegger, Wprowadzenie do metafizyki, przeł. Robert Marszałek (Warszawa: WN PWN, 2000), 33: „Tak jak do tej właśnie rzeczy [kawałka kredy] należy znajdowanie się tutaj, tak samo należy do niej móc nie być tutaj i nie być tej wielkości. Możliwość przesuwania jej po tablicy i zużywania nie jest czymś, co do tej rzeczy tylko dołączamy w myśli". Analiza Heideggera ukierunkowana jest tu jednak przede wszystkim na ukazanie, że bycie kredy rozciąga się poza jej prostą obecność (Mahon O'Brien, Nothing Against Natality", w: Towards a New Human Being, ed. Luce Irigaray, Mahon O’Brien, Christos Hadjioannou (London: Palgrave Macmillan, 2019), 5. 
które je przekształca, znacząco przyczynia się do odsłonięcia ich bycia, którego to problemu Heidegger nie rozwija w swoich diagnozach.

Ktoś mógłby przytomnie zauważyć, że w Byciu i czasie znajdziemy słynny fragment poświęcony zepsutemu narzędziu. Analiza Heideggera nie podejmuje jednak $w$ tym przypadku kwestii tego, że jest on zepsuty z powodu wpływu jakiegoś innego bytu (przez umiejętne użycie lub dlatego, że korniki zjadły drewnianą rączkę itp.). Heidegger skupia się na tym, że źle działająca rzecz nadal jest lub ujawnia się jako coś poręcznego (funkcjonalnego), tylko po prostu nie może być użyta $\mathrm{w}$ danym momencie. Innymi słowy, Heidegger nie zastanawia się, jakie znaczenie dla ujawnienia się swoistości konkretnego narzędzia ma jego zniszczenie wynikające z ekspozycji na oddziaływanie innych bytów, które jest nieuniknione w przypadku relacji z nimi. Tymczasem wydaje się, że jeśli chcemy, aby odsłoniło się przed nami bycie tego konkretnego młotka, nie wystarczy myśleć o nim tylko poprzez pryzmat jakiejś funkcjonalności wspólnej dla wszystkich tego rodzaju obiektów, ale należy raczej wziąć pod uwagę jego naprawdę własne możliwości. Odnosząc to do naszego przykładu: każdy młotek służy do wbijania gwoździ, ale ten stracił taką zdolność i wydaje się to mieć zasadnicze znaczenie dla jego bycia tym, a nie innym indywiduum.

Zlekceważenie znaczenia powyższej zmiany zdaje się podważać wysiłki Heideggera, by przedstawić istoczenie się bycia jako związane $\mathrm{z}$ odsłanianiem poszczególności - unikatowości każdego bytu ${ }^{13}$, a nie jego taksonomiczną przynależnością do określnego rodzaju, typu czy klasy. Zadając pytanie o bycie, Heidegger nie przejawia większego zainteresowania kwestią zmienności poszczególnych rzeczy, która ma swoje podłoże we wzajemnych związkach między bytami. To zaś stoi w sprzeczności z naszym codziennym doświadczeniem. Czy nie jest tak, że czyjeś lub czegoś bycie odsłania się przed nami - rzecz jasna w zgodzie ze swoim migotliwym, trudnym do uchwycenia charakterem - gdy zastanawiamy się, jakiego rodzaje relacje $\mathrm{z}$ innymi istotami sprawiły, że stał się taki, a nie inny? Na przykład, co musiało się stać z nauczycielem, który najwyraźniej stracił wiarę w młodych ludzi, lub dlaczego ta ławka $\mathrm{w}$ parku jest $\mathrm{w}$ tak złym stanie (omszała, oszpecona graffiti itp.), lub na jakie doskonałe warunki natrafił krzew jaśminu, że rośnie tak dobrze?

By jednak możliwie precyzyjnie postawić problem (braku) zmienności bytów u Heideggera, warto dokonać pewnych rozgraniczeń. W jego ontologii można bowiem dostrzec podwójną perspektywę w oglądzie zmienności: ogólnych struktur ${ }^{14}$ oraz bytów indywidulanych. Moż-

13 Rafael Winkler, Philosophy of Finitude Heidegger, Levinas and Nietzsche (London: Bloomsbury, 2018), 4 .

${ }_{14}$ Catherine Malabou, The Heidegger Change. On the Phantastic in Philosophy, przeł. Peter Skafish (New York: SUNY Press, 2011), passim. 
na to pokazać na przykładzie rozumienia człowieka jako historycznego konstruktu, który zmienia się w toku dziejów (zapomnienia) bycia, i człowieka jako jednostki ${ }^{15}$.

W tym pierwszym znaczeniu Heidegger eksponuje, jak w kolejnych epokach dziejów (zapomnienia) bycia, wyrażających się w pracach czołowych dlań myślicieli, ulegają metamorfozie podstawowe określenia metafizycznego statusu człowieka (animal rationale, podmiot, wyraziciel woli mocy). Jakkolwiek zachodzeniem tych kolejnych transformacji rządzi jeden i ten sam mechanizm zapomnienia bycia - czy też chęć jego zdominowania - to niewątpliwie mamy tu do czynienia z permanentną zmiennością i brakiem jednej ustalonej definicji tego, kim jest człowiek. $Z$ drugiej jednak strony można zastanawiać się, czy koncepcja pasterza bycia nie jest pożądanym określeniem tego, kim jest człowiek. Wówczas mielibyśmy pewien ustalony, a-historyczny wzorzec, co wspierałoby tezę, że Heidegger nigdy nie wyzbył się całkowicie optyki transcendentalnej ${ }^{16}$.

Sprawa jeszcze bardziej komplikuje się przy ujęciu bycia człowieka, a później też bytów pozaludzkich, jako konkretnych jednostek. We wczesnym okresie swojej filozofii Heidegger podkreślał, że bycie jest zawsze moje (je meines) $)^{17}$, co także wpisuje się w semantykę "swoistości" bycia. Później mówił raczej o jednostkowości i każdowości (Jediesheit) - byciu tym, a nie innym - które są charakterystykami rzeczy jako rzeczy ${ }^{18}$. W Pytaniu o rzecz (1936) podkreśla, że jednostkowe rzeczy są kompletnymi bytami, zawsze dla siebie (je für sich), a nie jedynie egzemplarzami gatunku ${ }^{19}$.

Rodzi się jednak pytanie, czy ta swoistość bycia danego bytu jest stabilna, ustalona i niezmienna, czy też może ulec transformacji. Heideggerowi takie pytanie mogłoby się wydawać nonsensem lub symptomem uwikłania w tradycyjnie metafizyczne postrzeganie istoty danego bytu jako zespołu najważniejszych dla niego cech. Heideggerowskie ujęcie istoty - swoistości - jest ontologiczne i dotyczy niepodzielności fenomenu bycia-tym-właśnie. Na tej zasadzie ruch bycia może mieć tylko dwa kierunki: ujawnianie się i skrywanie. Dynamizm bycia rozumianego jako ujawnianie się swoistości bytu jest zatem związany albo ograniczony do

15 William Richardson, Heidegger. Through Phenomenology to Thought (New York: Fordham University Press, 2003), 242.

${ }^{16}$ Daniel Dahlstrom, „Heidegger's Transcendentalism”, Research in Phenomenology 35 (2005): 29-54.

17 Heidegger, Bycie i czas, 54.

18 Martin Heidegger, Pytanie o rzecz. Przyczynek do Kantowskiej nauki o zasadach transcendentalnych, przeł. Janusz Mizera (Warszawa: KR, 2001), 20-30.

${ }^{19}$ Heidegger, Pytanie o rzecz, 29-30, 149. 
zachodzenia różnicy ontologicznej ${ }^{20}$. Dużo mówiący jest w tym względzie komentarz z wykładu Koniec filozofii i zadanie myślenia, w którym Heidegger skłania się ku temu, by uznać, że jego wczesne opus magnum powinno być zatytułowane "prześwit i wyistaczanie” (Lichtung and Anwesenheit), a nie "bycie i czas" 21 .

Ta obserwacja stosuje się też do koncepcji jestestwa (Dasein) jako ontologicznej struktury umożliwiającej człowiekowi odkrywanie bycia (swojego, innych ludzi, rzeczy). Człowiek może decydować się, by korzystać z tej zdolności lub nie. To lejtmotyw Heideggerowskiej filozofii, który w późnych pracach jest wyrażony przez pojęcie usilności (Inständlichkeit), a we wczesnych przez z(a)decydowanie (Entschlossenheit)22. Dlatego kiedy Heidegger tłumaczy, że przyszłość (Zukunft) nie stanowi tego, co jeszcze nie stało się aktualne, ale jest przede wszystkim „szłością" (Kunft), z której jestestwo przychodzi do swych możliwości ${ }^{23}$, nie odnosi się do będącego $\mathrm{w}$ toku procesu formowania tożsamości, jak utrzymywał Sartre. W kolejnym akapicie czytamy: przyszłe jestestwo może być swym najbardziej własnym, ,jak/ono zawsze już było", tzn. swym "tym, co byłe" (Gewesen) ${ }^{24}$.

Heidegger, mówiąc o szczególnej ruchomości jestestwa - jego „szłości", wybieganiu ku przyszłości z byłości poprzez faktyczność - odnosi się do problemu wyboru (obrania kierunku), czy będzie ono właściwie („autentycznie”), czy też niewłaściwie (niezgodnie ze sobą), popadając $\mathrm{w}$ skrycie bycia w Się. W nieprzesądzonym charakterze jestestwa nie chodzi zatem o to, że może ono ulec jakimś istotnym przemianom ze strony innych bytów, ale że odkrywanie bycia wymaga nieustannego wysiłku przytomności. Dlatego w pewnym sensie jestestwo jest cały czas w ruchu, ale dotyczy to kwestii odsłaniania i skrywania bycia ${ }^{25}$, a nie jego ewentualnych metamorfoz.

Czy znaczy to, że dynamizm łączący się takimi zmianami, jak stawanie się pewniejszym siebie lub sfrustrowanym (w przypadku człowieka)

20 Tę różnicę między byciem jako faktem egzystencjalnym a byciem jako swoistością bytu trafnie oddaje Wawrzyniec Rymkiewicz, zestawiając zdania „przeszkadza mi jego istnienie (bycie)” oraz „przeszkadza mi jego sposób bycia” (Rymkiewicz, Formy istnienia, 327).

${ }^{21}$ Przekład zmieniony, w tłumaczeniu Krzysztofa Michalskiego mamy „prześwit i obecność", zob. Martin Heidegger, Koniec filozofii i zadanie myślenia, przeł. Krzysztof Michalski, w: Martin Heidegger, Ku rzeczy myślenia, przeł. Krzysztof Michalski, Janusz Mizera, Cezary Wodziński (Warszawa: Aletheia, 1999), 99; por. tenże, Zur Sache des Denkens (Frankfurt am Main: Vittorio Klostermann, 2007 (GA14)), 90.

${ }^{22}$ Takie tłumaczenie proponuje Jacek Filek, by podkreślić moment podejmowanie decyzji, który może niknąć w słowie zdecydowanie kojarzącym się z pewnością (zob. Jacek Filek, Etyka. Reinterpretacja (Kraków: Homini, 2014), 212-213).

${ }^{23}$ Heidegger, Bycie i czas, 456.

24 Tamże, 457.

25 Zob. O’Brien, „Nothing Against Natality”: 227. 
albo coraz okazalszym lub zmizerniałym (w przypadku bytów pozaludzkich) w zależności, odpowiednio, od posiadania lub braku satysfakcjonujących relacji interpersonalnych, dobrej ilości światła słonecznego i opadów, nie ma żadnego znaczenia ontologicznego ${ }^{26}$ Czy byty są impregnowane na tego typu zmiany $\mathrm{w}$ tym sensie, że takie przemiany są obojętne dla ich bycia? Ontologia Heideggera zdaje się to właśnie sugerować.

By jeszcze precyzyjniej wskazać związaną ze wzajemnym wpływem bytów lukę w ontologii Heideggera, warto nawiązać do Arystotelesowskiej analizy fenomenu działania-doznawania. W szczególności traktat O powstaniu i niszczeniu pozwoli nam lepiej zrozumieć, w jakim sensie doznawanie, które przekształca jeden byt, jest nieodłączne od działania nań drugiego bytu.

\section{Arystotelesowskie doznawanie-działanie}

Relacja myśli Heideggera i dzieła Arystotelesa to temat obejmujący wiele wątków, które trudno pomieścić w jednej książce ${ }^{27}$. Do najważniejszych z nich należą splatające się ze sobą zagadnienia takie jak: prawda (aletheia) jako od-krytość, logos jako nieodłączność myślenia i języka, który cechuje się przede wszystkim zdolnością do odkrywania-skrywania, physis jako ruch(omość) istoczenia bycia, czyli jego odsłaniania, czy poiesis, które Heidegger odnosi do „dopuszczania wyistaczania”, sprzeciwiając

${ }^{26}$ Wydaje się, że w ontologii Heideggera z afektywnością jest związana jedynie koncepcja nastrojów. Jednak, po pierwsze, dotyczą one relacji między jestestwem a byciem, a nie jestestwem i innymi bytami, oraz, po drugie, Heidegger nie zastanawia się nad tym, czy dany człowiek zmienia się w zależności od doznawania określonych nastrojów - czy częstotliwość doświadczania nastroju nudy lub lęku trwale go przekształca. Heidegger czyni to oczywiście programowo, ponieważ skupia się na kwestii ujawniania bycia jako wykraczającego poza obecność. Niemniej z powyższych powodów koncepcja nastrojów nie dotyczy interesującego nas problemu afektywności bytów ugruntowanej w ich interakcjach.

27 By ograniczyć się do wyboru prac z ostatnich lat, można wymienić następujące: Walter Brogan, Heidegger and Aristotle. The Twofoldness of Being (Albany: State University of New York, 2005); Bogdan Minca, Poiesis: zu Martin Heideggers Interpretationen der aristotelischen Philosophie (Würzburg: Königshausen und Neumann 2006); cały numer Heidegger-Jahrbuch: Heidegger und Aristoteles 3 (2007); Piotr Pasterczyk, „Znaczenie fenomenologicznych interpretacji Arystotelesa dla genezy fundamentalnej ontologii Martina Heideggera", Archiwum Historii Filozofii i Myśli Społecznej 50 (2010): 227-235. Ponadto we wszystkich najważniejszych, całościowych opracowaniach myśli Heideggera zawsze znajdziemy rozdział lub dłuższy ustęp poświęcony Arystotelesowi: Otto Pöggeler, Droga myślowa Martina Heideggera, przeł. Bogdan Baran (Warszawa: Czytelnik 2002), 356-366; Richardson Wiliam, Heidegger, Through Phenomenology to Thought (New York: Fordham University Press 2003), 309-316; Mizera, W strone filozofii niemetafizycznej, 30-36. 
się zawężeniu go do łacińskiego creatio w sensie tworzenia typowego dla transcedentalnej świadomości podmiotu.

To ostatnie pojęcie pozostaje $\mathrm{w}$ istotnym związku $\mathrm{z}$ terminem poiein - "działanie”. W licznych tekstach Heideggera o Arystotelesie oraz poświęconych mu komentarzach nie mogło zabraknąć jego analizy. W wykładzie poświęconym IX księdze Metafizyki (GA33) Heidegger omawia je w kontekście potencjalności rozumianej jako uleganie (paschein) wpływom działania.

Przypomnijmy pokrótce, że w Księdze Theta (1046a 11-16) Arystoteles, rozwijając koncepcję potencji (możności, dynamis) właściwej bytom, stwierdza najpierw, że byty mają dwa rodzaje potencjalności. Pierwsza dotyczy ulegania zmianom (paschein) wywołanym przez inne byty, druga zaś polega na nieuleganiu zmianom na gorsze i zniszczeniu, jakie zagraża ze strony innego bytu ${ }^{28}$. W dalszym ciągu (17-20) Arystoteles dodaje, że o potencjalności mówi się też, mając na myśli albo tylko działanie (poiein), albo doznawanie (paschein), ale stwierdza, że są one tą samą potencja ponieważ aby posiadać możliwość doznawania, byt musi mieć potencję działania, sprawiająca, że coś innego może doznawać. Arystoteles nie rozwija tu jednak tej myśli, dopowiadając tylko, że należy mieć na uwadze, że są one różne tylko w tym sensie, że bierna potencjalność znajduje się przedmiocie - $\mathrm{w}$ danym momencie doznającym, a aktywna w działającym ${ }^{29}$.

Heidegger w swojej interpretacji skupia się na pierwszym fragmencie tych rozważań, rozróżniającym uleganie i nieuleganie zmianom. Ten pierwszy typ potencji Heidegger przedstawia jako siłę znoszenia (die Kratf zum Erleiden). Tłumaczy, że powinniśmy to jednak rozumieć nie jako znoszenie, tj. doznawanie, bolesnego cierpienia, ale raczej zdolność do ś-cierpienia czegoś $^{30}$. W tym sensie byłoby to znoszenie jako pozwalanie (Zulassen): gdy na przykład bryła gliny pozwala, aby ją uformować. Dlatego też Heidegger proponuje, aby taką potencję ująć jako „znośność" (Ertragsamkeit), której szczególnym rodzajem jest wytrzymałość (Aushaltsamkeit). Heidegger ttumaczy, że ta wytrzymałość w pozwalaniu jest tożsama z nierobieniem czegoś przeciwko (temu, co się dzieje), czyli pozwalaniu, aby to się zadziało ${ }^{31}$. Innymi słowy, pierwszy typ potencji to nie-stawianie oporu (Nichwiderstehen) ${ }^{32}$. Drugi typ potencji wskazany

28 Arystoteles, Metafizyka, przeł. Kazimierz Leśniewski (Warszawa: WN PWN, 2009), 161.

29 Tamże.

${ }^{30}$ Martin Heidegger, Aristoteles: Metaphysik IX. Von Wesen und Wirklichkeit der Kraft (Frankfurt am Main: Vittorio Klostermann, 1990 (GA33)), 88: „nich als Leiden (...) sondern Erleiden in dem Sinne von «er leidet es nicht»: er lässt es nicht zu gern".

31 Heidegger, GA33, 88.

32 Tamże. 
przez Arystotelesa Heidegger ujmuje jako opór (Widerstehen), czyli nie-znoszenie (Nichtleiden), nie-tolerowanie (Nichtdulden) ${ }^{33}$.

Dla Heideggera w koncepcji autora Metafizyki najważniejsze jest to, że problematyka oporu (stawiania go lub nie) wysuwa się na pierwszy plan przed działanie, gdy mowa o dynamis ${ }^{34}$. Heidegger twierdzi, że taki tok wywodu Arystotelesa nie jest przypadkowy, ale wynika z samej natury rzeczy ${ }^{35}$. Poiein, działanie, choć oczywiście zawarte w zjawisku doznawania, nie jest wobec niego pierwotne. Według Heideggera to, co stawia opór, jest najbardziej podstawową postacia, w której doświadczamy siły. Oznacza to, że najpierw doświadczamy tego, co się opiera, a nie samego oporu. Siłą zatem nie jest sam opór, ale to, co się opiera. Ono jest tym, co mocarne (Kraftige), i samą mocą (Kraft) ${ }^{36}$.

Taka wykładnia potencji u Arystotelesa może wydawać się nieoczywista, ale biorąc pod uwagę, że "każdy myśliciel myśli jedną myśl”, rozpoznajemy $\mathrm{w}$ tej interpretacji Heideggerowską koncepcję prawdy jako od-krytości, czyli skrytości (oporu) bycia, z której zawsze dopiero je wydobywamy, poprzez to, że (nie stawiając oporu) pozwalamy mu się istoczyć, co wymaga wysiłku usilności w poskramianiu zapędów ludzkiej subiektywności. Heidegger zgodnie ze swoją optyką odczytuje tu zatem całą dyskusję o potencji przez pryzmat mechanizmów istoczenia się - odsłaniania - bycia. Można jednak zastanowić się, czy nie zubaża to diagnozy Arystotelesa dotyczącej tego, jak bardzo potencja danego bytu, właściwa jej dynamika, jest związana z innymi bytami i ich oddziaływaniem.

O istotności tej obserwacji dla Arystotelesa niech świadczy fakt, że omawia on ją bardziej szczegółowo w traktacie O powstawaniu $i$ niszczeniu. Jak zauważają komentatorzy tego mniej znanego i niewielkiego objętościowo tekstu, dotyczy on fizyki Arystotelesa ${ }^{37}$, o której, przypomnijmy, Heidegger miał lepsze zdanie niż o metafizyce ${ }^{38}$.

Podstawowym problemem tego traktatu, co już sygnalizuje tytuł, jest powstawanie i niszczenie ciał. Arystoteles odróżnia powstawanie i niszczenie od przemiany, stwierdzając, że o ile zmiana dotyczy tylko przypadłości, to mamy do czynienia z przemianą bytu, kiedy zaś zmiana dojdzie do istoty i materii, dochodzi do zniszczenia danego bytu ${ }^{39}$. Inny-

33 Tamże, 89.

34 Tamże, 90.

35 Tamże, 91.

36 Tamże, 91; zob. Brogan, Heidegger and Aristotle, 122.

37 Pokulniewicz, Arystoteles. O powstawaniu i niszczeniu, 11.

38 Heidegger, Bycie i czas, 33; Daniel Sobota, „Ontologia przyrody we wczesnej filozofii Martina Heideggera", Filo-Sofija 13-14 (2011/2-3): 745-746.

39 Arystoteles, O powstawaniu $i$ niszczeniu, przeł. Andrzej Pokulniewicz, w: Andrzej Pokulniewicz, Arystoteles. O powstawaniu $i$ niszczeniu. Tekst, przekład $i$ studia (Warszawa: Wyd. Księży Werbistów, 2008), 114. 
mi słowy, powstawanie i niszczenie polega na zmianie $\mathrm{w}$ całości $\mathrm{z}$ tego oto $\mathrm{w}$ to oto (dezintegracji $\mathrm{w}$ inną rzecz) lub przekroczenia pewnego minimum, poniżej którego byt jednostkowy nie może być uznany za tożsamy ${ }^{40}$.

Kluczowe dla tematu naszych rozważań jest to, że te zmiany wynikają ze zjawiska działania i doznawania. Arystoteles w pierwszej kolejności podkreśla nieredukowalną niepodzielność tego fenomenu, mówiąc o wzajemności między bytami ${ }^{41}$. Aby mogło zajść działanie, musi być to, co zdolne do przyjęcia skutków tego działania.

W dalszym ciągu Arystoteles wyjaśnia, że działanie-doznawanie polega na upodobnieniu się rzeczy doznającej do działającej: ogień ogrzewa, zimno oziębia ${ }^{42}$. Należy mieć na uwadze, że to podobieństwo jest zawsze względne. Przykładowo, lekarz i wino, uosabiając zdrowie, na różny sposób uzdrawiają to, co chore ${ }^{43}$.

Kwestia podobieństwa i odmienności jest ważnym zagadnieniem dla pełniejszego określenia zasady działania-doznawania. Według Arystotelesa przyczyna sprawcza (agens) i przyczyna podlegająca wpływom tej pierwszej (pacjens) są czymś podobnym w tym sensie, że muszą mieć jedną naturę jako podmiot ${ }^{44}$. Arystoteles tłumaczy, że białość nie wpłynie na linię, chyba że tylko przypadłościowo, zmieniając czarną linię $\mathrm{w}$ białą ${ }^{45}$. Białość może przemienić tylko inną barwę istotowo, np. czarność. Z drugiej strony pewna odmienność jest niezbędna, aby mogło zajść działanie-doznawanie: ogień ogrzewa rzecz od niego chłodniejszą ${ }^{46}$ lub może oddziałać na inny ogień, tylko jeśli jest od niego więk$\mathrm{szy}^{47}$. Dlatego też lekarz leczy (dając określone zalecenia) inaczej niż wino (wspomagając organizm): podobieństwo między lekarzem jako innym człowiekiem a chorym jest innego typu niż między człowiekiem a winem, które łączy to, że są bytami materialnymi.

Podsumowując, w O powstawaniu i niszczeniu Arystoteles pokazuje, jak bardzo znacząco byty wpływają na siebie, przekształcając się wzajemnie, aż po zniszczenie. To właśnie zjawisko działania-doznawania, jakie zachodzi między bytami, tłumaczy, skąd biorą się przemiany

40 Pokulniewicz, Arystoteles. O powstawaniu i niszczeniu, 11, 17; Arystoteles, O powstawaniu i niszczeniu, 128.

${ }^{41} \mathrm{~Np}$. Arystoteles, O powstawaniu i niszczeniu, 144, 164. Z tego powodu często te dwa terminy są przez badaczy zapisywane z użyciem dywizu („,działanie-doznawanie"), zob. Pokulniewicz, Arystoteles. O powstawaniu i niszczeniu, 67; Brogan, Heidegger and Aristotle, 37.

42 Arystoteles, O powstawaniu i niszczeniu, 150.

43 Tamże, 152.

44 Tamże, 144.

45 Tamże, 150.

46 Tamże, 152.

47 Tamże, 148. 
W nas samych i otaczającym nas świecie. Jest to oczywiście tylko jeden z wątków dotyczących problematyki aktu i potencji, której złożoność i bogactwo wykraczają daleko poza ów aspekt. Celem jego powyższej prezentacji było wyeksponowanie uniwersalności zakresu afektywności, który wychodzi poza dychotomię bytów ludzkich i pozaludzkich.

Oczywiście, Arystoteles pozostawia nas ze znaczącym niedosytem, np. w kwestii określenia trwałości zmian czy bliższego wyznaczenia granicy między zbiorem przypadłości a istotą bytu, której naruszenie grozi jego destrukcją. To ostatnie zresztą założenie, czyli utożsamienie istoty ze zbiorem określonych cech, podobnie jak zespół poglądów na substancję, formę i materię, sytuuje Arystotelesa po stronie tradycji metafizyki obecności. Niemniej Arystoteles nie pozostawia wątpliwości dotyczących tego, jak bardzo dla naszego stanu, naszej kondycji, ważne są inne byty.

Heidegger natomiast, jak starałam się powyżej wykazać, pomija problematykę wzajemnego oddziaływania bytów, co skutkuje przedstawieniem niepełnego obrazu relacji między nimi. Nie znaczy to jednak, że ontologia Heideggera wyklucza możliwość wyartykułowania tego zagadnienia. Wychodząc poza ortodoksję studiów Heideggerowskich, spróbuję wyartykułować, jak kwestia oddziaływania mogłaby się przedstawiać w ontologii o proweniencji Heideggerowskiej. Ten eksperyment będzie polegał na pokazaniu, że poprzez zmiany, jakie powodują w nas inne byty, a my w nich, może ujawniać się bycie - odsłaniać się istoczenie swoistości. Tę zależność proponuję ująć jako „kształtowalność”.

\section{Kształtowalność}

Wiodące dla naszych rozważań jest pytanie dotyczące tego, jak zmiany $\mathrm{w}$ bytach przekładają się na ich bycie. Tłumacząc to zaś na kategorie stricte Heideggerowskie, można zastanowić się, w jakim związku pozostaja zmiany ontyczne do ontologicznego charakteru bytu. Możliwą odpowiedzią jest stwierdzenie, że zmiany zachodzą wyłącznie na poziomie ontycznym, a ontologicznie byt pozostaje taki sam. Takie rozdzielenie gubiłoby jednak sens różnicy ontologicznej, która nie tylko wskazuje dwuaspektowość bytu jako będącego, ale równocześnie podkreśla nieodłączność ontyki i ontologii ${ }^{48}$. Nawiązując do koncepcji postfenomenologicznych, można powiedzieć, że tylko poprzez to, co ontyczne, można dotrzeć i odsłonić to, co ontologiczne (które z kolei gruntuje to, co ontyczne) ${ }^{49}$.

${ }^{48}$ Zob. Martin Heidegger, Protokół z seminarium na temat wykładu "Czas i bycie”, przeł. Janusz Mizera, w: Martin Heidegger, Ku rzeczy myślenia, 46.

49 Don Ihde, Heidegger's Technologies: Postphenomenological Perspectives (New York: Fordham University Press, 2010), 31. 
Taka rehabilitacja aspektu ontycznego ma pokazywać, że myśląc o bycie, wychodzimy poza ontykę, co jednak stanowi niezbywalny moment zachodzenia różnicy ontologicznej, a nie coś podrzędnego czy wtórnego. Gdy widzimy określone cechy bytu, to nie zatrzymujemy się na nich jako właściwościach ontycznych, ale postrzegamy je w ich wymiarze ontologicznym.

Niech przykładem będą nasze zimowe buty. Ich zadrapania i odbarwienia nie stanowią tylko zmian ontycznych, ale mogą być ujęte jako to, co powstało w wyniku działań innych bytów (noszenia ich przez nas, soli na chodniku, wilgoci itd.), które, z drugiej strony, mogły być przyjęte przez ów byt ${ }^{50}$. Równocześnie musimy mieć na uwadze to, że nasze buty też oddziałują na szereg innych bytów, zostawiając wyżłobienia we wspomnianych choćby płytach chodnikowych, stopniach schodów, dywanikach samochodowych. Zarazem te wszystkie ślady są nieodłączne od sportretowanych tu rzeczy. Czy zatem w tych wszystkich zmianach, jeśli pomyślimy je jako ugruntowane w relacyjności bytów, nie przebłyskuje nam bycie tej konkretnej pary butów?

Ontyka, co podkreśla Heidegger, to nie tylko domena tego, co traktujemy jako materialne, ale także sfera psychiki ${ }^{51}$. Dlatego też przykładem interesującej nas zmiany może być sytuacja, gdy dawniej uśmiechnięta, pełna werwy osoba wskutek określonych doświadczeń, które w niej rezonuja, traci swój entuzjazm i staje się zgorzkniała oraz zatruwająca życie innym. Czy w tej metamorfozie nie ujawnia się bycie tej osoby - czyli to, co jej własne, swoiste dla niej i jej dziejów?

Aby oddać tę dychotomiczną właściwość, związaną ze zdolnością do kształtowania i bycia kształtowanym, sugeruję nazwać ją

50 Ten przykład może nasuwać skojarzenia ze słynną interpretacją obrazu przedstawiającego buty, autorstwa Van Gogha. Heidegger przedstawia je jako brudne i znoszone, podczas gdy na obrazie Van Gogha, co dziwi filozofa, "nie są nawet oblepione grudami ziemi z roli lub z polnej drogi” (Heidegger, "Źródło dzieła sztuki", przeł. J. Mizera, w: Martin Heidegger, Drogi lasu (Warszawa: Aletheia, 1997), 20. Heidegger na użytek swoich rozważań wyobraża sobie, że należą one do chłopki, które zakłada je na co dzień do ciężkiej pracy. Heidegger nie zastanawia się jednak nad tym, jak jej oddziaływanie zmienia tę konkretną parę butów, ale podobnie jak w przypadku młotka w Byciu i czasie jego namysł kieruje się ku odkrywaniu ich ogólnie narzędziowego charakteru.

51 M.in. w Byciu i czasie, gdzie krytykuje ontyczne podejście do prób uchwycenia istoty człowieka jako złożenia ciała, duszy i ducha, zob. Heidegger, Bycie i czas, 61. 
„kształtowalnością"52 (w języku niemieckim byłaby to Gestaltbarkeit ${ }^{53}$ ). Ten termin ma się odnosić do możliwie szerokiego zakresu różnorodnych interakcji między bytami, które powodują w nich zmiany, poprzez które może ujawniać się ich bycie. Co istotne, to kształtowanie nie powinno być rozpatrywane $\mathrm{w}$ kategoriach dominacji lub hierarchii. Bycie kształtowalnymi bytów nie odnosi się do ich ontologicznej słabości czy też podrzędności wobec innych bytów, które je kształtują i jako takie miałyby być nadrzędne względem nich. Takie wyobrażenie powinniśmy odrzucić w przypadku kształtowalności, która odnosi się do nieusuwalnego powiązania wszystkich bytów. Ani my nie jesteśmy impregnowani na oddziaływanie tych bytów, ani one nie są impregnowane na nasze oddziaływanie.

Należy podkreślić, że zmiany pojawiąjące się wskutek tego oddziaływania nie muszą być negatywne. Kształtowalność nie jest tożsama $\mathrm{z}$ byciem podatnym na zranienie. Kształtowanie nie jest ograniczone do pogarszania się kondycji danego bytu ani nie może być jednoznacznie w ten sposób tłumaczone. Możemy pomyśleć na przykład o zaniedbanej roślinie. Ktoś zaczyna o nią dbać i dzięki temu roślina odzyskuje swoje siły witalne i staje się jeszcze piękniejsza niż wcześniej. W takim kształtowaniu też można, jak sądzę, dostrzec ujawniające się bycie. Również stawanie się bardziej ostrożnym i refleksyjnym (co oznacza zarazem utratę spontaniczności) wskutek różnorodnych zdarzeń w naszym życiu jest symptomem kształtowalności, dzięki której może odsłonić się (nasze) bycie.

Kluczową kwestią jest jednak to, że nie możemy być i zarazem uniknąć kształtowania. Kształtowanie jako takie jest niezależne od woli: zachodzi bezwiednie i w sposób nieunikniony ${ }^{54}$. Mając kontakt z in-

${ }^{52}$ Jego pokrewieństwo z koncepcją „plastyczności”, jako równowagi między nadawaniem i przyjmowaniem formy, wprowadzoną przez Catherine Malabou, jest odległe. Malabou opisuje wewnętrzną możliwość zmiany w bycie czy też - precyzyjniej - możliwość samodestrukcji wskutek wypadku, traumy lub bez szczególnego powodu. W rezultacie takiej przemiany, której impuls nie pochodzi z zewnątrz, miałby powstawać całkowicie nowy byt: dochodziłoby do radykalnego zerwania i zaprzeczenia wcześniejszej tożsamości, zob. Catherine Malabou, Ontologia przypadłości. Esej o plastyczności destrukcyjnej, przeł. Piotr Skalski (Warszawa: Fundacja Hr. Cieszkowskiego, 2017).

${ }^{53}$ Gestalt, czyli „kształt” czy „postać”, nie jest technicznym terminem w filozofii Heideggera (choć jako pojęcie niesie istotny bagaż filozoficznych konotacji). Właściwie jedyny ustęp, w którym to słowo odgrywa większą rolę, znajdziemy w $\mathrm{Na}$ myśle (GA 66, Besinnung), gdzie Heidegger łączy je jako „samowbudowywanie” ze "wchodzeniem w istoczenie” (Die Gestalt ist kein "Phänomen", sondern meaphysisch die Insichgestelltheit, das Aufstehen in die reine Anwesung) (Heidegger, Besinnung, 369) - co mogłoby znaczyć, że bycie istoczy się, wchodząc w określoną postać bytu.

${ }^{5}$ Tu można odnieść się do drugiego z rzadkich ustępów dotyczących zmian w bytach, gdzie Heidegger dodatkowo porusza kwestię tego, jak byty oddziałują na 
nym bytem - a nigdy przecież żaden byt nie znajduje się w próżni - nie można nie wpłynąć na niego i zarazem nie ulec jego wpływowi. Mogę oczywiście próbować ograniczyć ten wpływ lub w określony sposób go ukierunkować, ale nie mogę go całkowicie powstrzymać. Każdy krok zostawia ślad: zarysowania, mikro-wgłębienia. Czasem po prostu stają się one widoczne dopiero $\mathrm{w}$ dalszej perspektywie, jak choćby w wypadku ścieżek wydeptanych na trawniku, którymi przechodnie skracają sobie drogę.

Na tej samej zasadzie każde spotkanie w ten czy inny sposób wzmacnia nasze zaufanie lub czyni nas podejrzliwymi, pozwala nam stawać się dojrzalszymi bądź utrudnia porozumiewanie się z innymi, czyni nas bardziej otwartymi lub jeszcze bardziej zobojętniałymi, przekształcając nas. Można oczywiście twierdzić, że możemy stawiać opór tym zmianom, ale czy nie jest tak, że stajemy się wówczas bardziej zatwardziali, hardzi, okrzepli, silniejsi? W takim wypadku należałoby zaś mówić o zmianie i pewnym przekształceniu. Te zmiany nie powinny być jednak traktowane jako naruszenie naszej swoistości. Wręcz przeciwnie, to właśnie zza nich, jeśli spróbujemy je rozumieć ontologicznie, może się ona ujawniać.

To kształtowanie jest nam ontycznie tak bliskie, że ontologicznie staje się jak najdalsze, co wpisuje je w koncepcję różnicy ontologicznej. Nawet kiedy czekam na przystanku autobusowym w milczącym towarzystwie anonimowych współpasażerów, oddziałują oni na mnie, a ja na nich. Za każdym razem, gdy nikt mnie nie niepokoi, osadza się we mnie poczucie codziennego bezpieczeństwa i monotonii, które wpływa na mnie. Dlatego można uznać, że w takiej sytuacji także zachodzi pewne kształtowanie, pomimo że zazwyczaj pozostaje niezauważone, jak w przypadku leżących na brzegu kamieni obmywanych przez kolejne fale.

Ten skrywający się charakter kształtowalności oraz jej istotowa niezależność od woli sprawiają że można próbować włączyć koncepcję kształtowalności w ontologię Heideggera, zważywszy ponadto na ideę wielowymiarowości bycia ${ }^{55}$. Bycie ujawnia się w różnorodnych i skom-

siebie. Jest to krótki fragment w Hermeneutyce faktyczności, w którym Heidegger opisuje stól, którego blat trochę zniszczyli chłopcy: „Tu i ówdzie widać rysy - przy tym stole majstrowały urwisy; owe rysy nie są jakimiś przypadkowymi uszkodzeniami lakieru, albowiem to właśnie urwisy je zrobiły, i robią to nadal" (Martin Heidegger, Ontologia (Hermeneutyka fatyczności), przeł. Mateusz Bonecki, Jakub Duraj (Nowa Wieś: Wyd. Rolewski 2007), 94). Te zmiany, jak zaznacza sam Heidegger, powstały jednak celowo. Natomiast koncepcja kształtowalności dotyczy nieustannego wzajemnego wpływu bytów na siebie, obejmującego nie tylko działania o charakterze celowym, ale też oddziaływanie, które znajduje się poza naszą decyzyjnością.

${ }_{55}$ Zob. Jussi Backman, „Radical Contextuality in Heidegger's Postmetaphysics: The Singularity of Being and the Fourfold", w: Paths in Later Heidegger's Thought, ed. Günter Figal i in. (Indiana University Press, 2020), 220. 
plikowanych konfiguracjach, w których jego różne odsłony nakładają się na siebie. Na tej zasadzie kształtowalność jest koniecznie ugruntowana w czasowości i światowości, choć pokazanie tego wymaga ich rewizji lub - precyzyjniej - wyeksponowania ich wewnętrznego powiązania. W Byciu i czasie są to dwa kluczowe wymiary - struktury - ujawniania się bycia. Dlatego tak zastanawiająca jest skąpa analiza związków między nimi przeprowadzona przez Heideggera. Jest ona relatywnie krótka i niekonkluzywna. Trudno na jej podstawie powiedzieć coś więcej o stosunku, w jakim pozostaje sens bycia odkrywany w perspektywie czasowości do tego, który odsłania się przez światowość. Trudno pozbyć się wrażenia, że sam Heidegger nie był zadowolony z zaproponowanego przez siebie rozwiązania ${ }^{56}$.

Problem kształtowalności może rzucić nowe światło na ich związek, ponieważ jest ona odniesiona do obu tych wymiarów. Jeśli chodzi o światowy charakter bycia, nieuniknioność kształtowania zakłada, że żaden byt nigdy nie jest odizolowany od pozostałych bytów. Tym samym jest nieustannie wystawiony na ich oddziaływanie. Ta uwaga kieruje nas ku czasowości, choć musimy pamiętać, że w koncepcji kształtowalności nie chodzi o to, że zmiany mogą być zaobserwowane dzięki upływowi czasu. Ważniejsza jest tu raczej symultaniczność jego ekstaz. Odnośnie do przeszłości oznacza to, że ślady powstałe w wyniku oddziaływań innych bytów pozostają nieodwracalnie $\mathrm{w}$ danym bycie. Nie mogą być cofnięte ani wymazane. Teraźniejszość z kolei dotyczy tego, że byty są każdorazowo otwarte na zmianę. Byty nieustannie na siebie wpływają i tego zjawiska nie można ani zatrzymać, ani zawiesić. Przyszłość z kolei związana jest ze zmianami, które dopiero mają nadejść. Jak długo dany byt jest, będzie kształtowany i będzie kształtował inne byty. A skoro te zmiany mają źródło w powiązaniu bytów, widzimy, że tylko przez ściślejsze połączenie światowego i czasowego aspektu bycia możemy rozwijać ideę kształtowalności.

Koncepcja kształtowalności nie podważa tego, że swoistość bycia to prosty, niepodzielny fenomen - bycie-właśnie-soba. Pokazuje ona jedynie, że ta swoistość może odkryć się w zmianach, jakie dostrzegamy w bycie: zadrapaniach, bliznach, zgrubieniach, wyżłobieniach. Musimy tylko traktować je nie jako określone ontyczne właściwości, ale jako to, co jest ugruntowane $\mathrm{w}$ relacyjności bytów. To z kolei pomaga nam zrozumieć, że te przekształcenia nie są rezultatem upływu czasu, ale aktywności innych bytów. To nie czas nas kształtuje, ale inne byty. Ta obserwacja

56 Ogranicza się ono do tego, że sensowność świata, możliwość odkrywania bytu wewnątrzświatowego, jest związana z czasowością jestestwa, gdy uprzytamnia ono sobie, że kieruje się zawsze "przed coś” (z czym można powiązać ekstazę byłości), „ze względu na siebie” (ekstaza przyszłości), „ażeby (np. wykonać określone zadanie)" (ekstaza współczesności), zob. Heidegger, Bycie i czas, 458-461. 
ma kluczowe znaczenie dla ujęcia kwestii kształtowalności w kontekście problemu bycia-ku-śmierci.

\section{Przybliżanie-ku-śmierci}

Traktat $O$ powstawaniu i niszczeniu łączy kwestię afektywności bytów z ich możliwym zniszczeniem. Według Arystotelesa oddziaływanie-doznawanie powoduje zmiany, te zaś, jeśli dotykają istoty bytu, a nie tylko przypadłości, skutkują jego zniszczeniem. Lekcja, która daje nam tu Arystotelesa, polega na porzuceniu przekonania, że to za sprawą czasu przestajemy istniećs7. Nie zabija nas czas, ale inne byty. To one moga nieść nam śmierć czy też do niej przybliżać.

Ontologia Heideggera może pomóc nam spojrzeć na ten problem $\mathrm{z}$ trochę innej perspektywy. Jak przypomnieliśmy na początku, zgodnie z jej założeniami bycie bytu odsłania się przez jego funkcjonowanie. Ołówek ujawnia własną swoistość - jako to, co służy do pisania - wtedy, gdy jest używany do pisania. Używanie ołówka - pisanie, temperowanie - prowadzi jednak do tego, że ołówek z-używa się, a właściwie jest z-używany przez piszącego, w kontakcie z innymi bytami (kartka, temperówką). Używanie $z$ jednej strony umożliwia więc istoczenie się bycia bytu, z drugiej strony przybliża kres tego bycia. Innymi słowy, poprzez zmiany powstałe $\mathrm{w}$ wyniku oddziaływania innych bytów prześwieca istoczenie się swoistości, jednak równocześnie te zmiany mogą powodować zniszczenie lub śmierć bytu.

Zatem kształtowanie wpisane w bycie - istoczenie - często w nieunikniony sposób przyczynia się do śmierci lub zniszczenia bytu. W analizie tego problemu, mając na uwadze fakt, że odnosimy się tu do ontologii Heideggera, musimy pamiętać o specyfice ujęcia bycia-ku-śmierci. Nie chodzi w niej o stwierdzenie, że człowiek jest śmiertelny lub że inne byty są zniszczalne, przemijalne etc. W koncepcji bycia-ku-śmierci Heidegger kładzie nacisk na to, że wizja kresu uprzytamnia nam nasze bycie - dzięki niej odkrywa się ono w swym indywidualnym (moim) charakterze: nie mogę na nikogo scedować własnej śmierci ${ }^{58}$.

Koncepcja kształtowalności wydobywa inny aspekt tego fenomenu. Mianowicie mojość bycia może odsłonić się przede mną gdy zaczynam rozumieć, że moimi działaniami, często wbrew mojej woli, mogę przybliżać innych do ich śmierci. Analogicznie, inni, nawet jeśli nie mają takiego zamiaru, mogą przyczyniać się do mojej śmierci swoim oddziaływaniem na mnie.

57 Które to przekonanie, dodajmy, jest silnie obecne w filozofii europejskiej, jak pokazuje Wawrzyniec Rymkiewicz (Rymkiewicz, Formy istnienia, 10).

58 Heidegger, Bycie i czas, 298-317. 
Weźmy za przykład muzealne artefakty. Ceną za to, by jak najdłużej trwały, jest ich odseparowanie od oglądających oraz działania czynników atmosferycznych. Im bardziej wartościowy eksponat, tym solidniejsze zabezpieczenia i osłony, a tabliczki z napisem „Nie dotykać!” większe. Dość czytelnie pokazuje to, że interakcje z innymi bytami są właśnie tym, co może spowodować zniszczenie danego bytu.

Jest jednak druga strona medalu. Kiedy rzeczy zostają niejako wyjęte z sieci oddziaływań, stają się niczym więcej niż muzealnymi artefaktami. Zyskanie takiego statusu na pewno można poczytywać jako nobilitację, ale równocześnie jest to silne ograniczenie sposobów, w jakie byt może się istoczyć. Nie chodzi tu tylko o zmianę kontekstu znaczeniowego ${ }^{59}$. Przez ograniczenie kontaktów z innymi bytami i tym samym ich oddziaływanie byty mogą być zakonserwowane, ale wskutek tego zostają spetryfikowane.

Wydaje się, że podobnie człowiek, nie chcąc ryzykować doznania krzywdy lub jakiejkolwiek zmiany w sobie samym, mógłby dążyć do zminimalizowania kontaktów z innymi ludźmi, a także bytami pozaludzkimi. Pytanie jednak, czy w takim odizolowaniu się mógłby się dalej istoczyć.

Kształtowalność odkrywa $\mathrm{w}$ ten sposób istotne napięcie $\mathrm{w}$ istoczeniu się bycia. $Z$ jednej strony można położyć nacisk na to, że byty umożliwiając innym bytom - będąc z nimi w relacjach i tym samym oddziałując na nie - odkrywanie (ich) bycia, mogą przyczyniać się tym do ich zniszczenia. $Z$ drugiej strony natomiast można powiedzieć, że oddziałując, byty przyczyniaja się do zniszczenia innych bytów, choć dzięki temu odkrywa się ich bycie. Bez względu na to, jak rozłożymy akcenty, zawsze w grze pozostają oba te wymiary istoczenia bycia.

\section{Podsumowanie}

Koncepcja kształtowalności - którą próbowałam tu wpisać w ontologię opartą na rozwiązaniach Heideggera - zakłada, że byty, będąc, nieuchronnie oddziałują i doznają zmian od innych bytów; kształtują i są kształtowane. Jest to nieredukowalny aspekt bycia, niezależny od

${ }^{59}$ Można to skontrastować z jeszcze innym fragmentem Bycia i czasu (477). Heidegger opisuje tu, jak niektóre rzeczy, na przykład te zebrane w muzeum, zmieniły się. Pisze, że zabytki są rzeczą przeszłości, „,minionego czasu”, ponieważ wraz z jego upływem uległy pewnym przemianom. Jednak to, że stało się to pod wpływem różnych czynników, tj. innych bytów, np. stoczyły je robaki, ma dla niego mniejsze znaczenie. Kluczową rolę odgrywa w tym wypadku według Heideggera zmiana kontekstu znaczeniowego. Takie podejście wydaje się jednak bardzo antropocentryczne i subiektywistyczne, a sam Heidegger zrezygnował z niego w późniejszym okresie swojej filozofii. 
woli - można próbować kształtować inne byty w określony sposób lub w określony sposób próbować odbierać to działanie, jednak pewne kształtowanie (bierne i aktywne) zachodzi zawsze.

Pojęcie kształtowalności nawiązuje do Arystotelesowskiej idei afektywności, tj. związku działania-oddziaływania, która tłumaczy, jak dla zmian w bytach kluczowe znaczenie ma oddziaływanie między nimi. Oczywiście kategorii Arystotelesowskich nie da się przełożyć bezpośrednio na ontologię Heideggera. Stanowią one raczej inspirację, by pokazać, że poprzez pryzmat śladów, jakie nieuchronnie pozostawiają w nas inne byty, a my w nich, może odkrywać się swoistość bytów - ich bycie. Te zmiany muszą być jednak rozumiane nie jako ontyczne cechy, ale jako to, co powstało dzięki wzajemnemu oddziaływaniu między bytami, Co ważne, tych zmian nie można w jednoznaczny sposób zaklasyfikować jako wzrostu lub zniszczenia. Perspektywa ujawniania tego, co najbardziej własne bytu, komplikuje to, równocześnie ujawniając niesamowitość istoczenia bycia.

\section{Bibliografia}

Arystoteles. 2009. Metafizyka, przeł. Kazimierz Leśniak. Warszawa: WN PWN.

Arystoteles. 2009. O powstawaniu i niszczeniu, przeł. A. Pokulniewicz. W: Andrzej Pokulniewicz. Arystoteles. O powstawaniu i niszczeniu. Tekst, przekład i studia. Warszawa: Wyd. Księży Werbistów.

Backman Jussi. 2020. „Radical Contextuality in Heidegger's Postmetaphysics: The Singularity of Being and the Fourfold". W: Paths in Later Heidegger's Thought, ed. Günter Figal i in, 190-211. Bloomington: Indiana University Press.

Baran Bogdan. 1988. Saga Heideggera. Kraków: Wyd. PAT.

Brogan Walter. 2005. Heidegger and Aristotle. The Twofoldness of Being. Albany: State University of New York.

Dahlstrom Daniel. 2005. „Heidegger's Transcendentalism”. Research in Phenomenology 35.

Don Ihde. 2010. Heidegger's Technologies: Postphenomenological Perspectives (New York: Fordham University Press), 31.

Filek Jacek. 2014. Etyka. Reinterpretacja. Kraków: Homini.

Heidegger Martin. 1990. Aristoteles: Metaphysik IX. Von Wesen und Wirklichkeit der Kraft. Frankfurt am Main: Vittorio Klostermann (GA33).

Heidegger Martin. 1996. Przyczynki do filozofii. Z wydarzania, przeł. Bogdan Baran, Janusz Mizera. Kraków: Wyd. Baran i Suszczyński.

Heidegger Martin. 1997. Besinnung. Frankfurt am Main: Vittorio Klostermann (GA66).

Heidegger Martin. 1997. „Źródło dzieła sztuki”, przeł. J. Mizera. W: Martin Heidegger, Drogi lasu, 6-65, Warszawa: Aletheia. 
Heidegger Martin. 1999. Ku rzeczy myślenia, przeł. Krzysztof Michalski, Janusz Mizera, Cezary Wodziński. Warszawa: Aletheia.

Heidegger Martin. 1999. List o "humanizmie”, przeł. Józef Tischner. W: Martin Heidegger. Znaki drogi, 271-312. Warszawa: Aletheia.

Heidegger Martin. 2001. Pytanie o rzecz. Przyczynek do Kantowskiej nauki o zasadach transcendentalnych, przeł. Janusz Mizera. Warszawa: KR.

Heidegger Martin. 2005. Bycie i czas, przeł. Bogdan Baran. Warszawa: WN PWN.

Heidegger Martin. 2007. Ontologia (Hermeneutyka fatyczności), przeł. Mateusz Bonecki, Jakub Duraj. Nowa Wieś: Wyd. Rolewski.

Heidegger Martin. 2007. Zur Sache des Denkens. Frankfurt am Main: Vittorio Klostermann (GA14).

Heidegger Martin. 2017. Podstawowe zagadnienia filozofii, przeł. Wawrzyniec Rymkiewicz. Warszawa: Fundacja hr. Cieszkowskiego.

Hoły-Łuczaj Magdalena. 2019. „Shapeability. Revisiting Heidegger's Concept of Being in the Anthropocene". Cosmos and History: The Journal of Natural and Social Philosophy 15, 1: 402-426.

Hoły-Łuczaj Magdalena. 2019. „Kształtowalność. Próba rewizji struktur Heideggerowskiego bycia w czasach antropocenu”. Analiza i Egzystencja 48: 65-87.

Malabou Catherine. 2011. The Heidegger Change. On the Phantastic in Philosophy, przeł. Peter Skafish. New York: SUNY Press.

Malabou Catherine. 2017. Ontologia przypadłości. Esej o plastyczności destrukcyjnej, przeł. Piotr Skalski. Warszawa: Fundacja Hr. Cieszkowskiego.

Minca Bogdan. 2006. Poiesis: zu Martin Heideggers Interpretationen der aristotelischen Philosophie. Würzburg: Königshausen und Neumann.

Mizera Janusz. 2006. W strone filozofii niemetafizycznej, Martina Heideggera droga do innego myślenia. Kraków: Wyd. UJ.

O’Brien Mahon. 2019. „Nothing Against Natality”. W: Towards a New Human Being, ed. Luce Irigaray, Mahon O'Brien, Christos Hadjioannou, 221-242. London: Palgrave Macmillan.

Piotr Pasterczyk. 2010. „Znaczenie fenomenologicznych interpretacji Arystotelesa dla genezy fundamentalnej ontologii Martina Heideggera". Archiwum Historii Filozofii i Myśli Społecznej 50: 227-235.

Pöggeler Otto. 2002. Droga myślowa Martina Heideggera, przeł. Bogdan Baran. Warszawa: Czytelnik.

Richardson William. 2003. Heidegger. Through Phenomenology to Thought. New York: Fordham University Press.

Rymkiewicz Wawrzyniec. 2015. Formy istnienia. Heidegger wedtug Arystotelesa. Warszawa: Fundacja Augusta hr. Cieszkowskiego.

Sobota Daniel. 2011. „Ontologia przyrody we wczesnej filozofii Martina Heideggera", Filo-Sofija 13-14 (/2-3): 737-769. von Denker Alfred, Holger Zaborowski, Günter Figal, Franco Volpi. 2007. Heidegger-Jahrbuch: Heidegger und Aristoteles 3.

Winkler Rafael. 2018. Philosophy of Finitude Heidegger, Levinas and Nietzsche. London: Bloomsbury. 
Wodziński Cezary. 2007. Heidegger i problem zła. Gdańsk słowo/obraz terytoria.

Żelazna Jolanta. 1984. „The «Essential Thought» of Martin Heidegger as a Continuation of Nietzsche's Philosophy of Time". Studia Filozoficzne 218, 1: 69-84.

\section{Streszczenie}

Ontologia Martina Heideggera, odkrywając wielowymiarowość bycia, wydaje się pomijać istotny dla jego ujawniania się wymiar. Ta luka dotyczy wzajemnego oddziaływania bytów, które pozostawia w nich ślady. Niniejsza próba zlokalizowania tego pominięcia podąża tropem Arystotelesowskiej idei działania-doznawania (O powstawaniu i niszczeniu, ks. I), tłumaczącej źródło zmian w bytach. Nawiązanie do tej Arystotelesowskiej koncepcji nie służy jednak wyłącznie do zilustrowania powyższej luki u Heideggera, ale stanowi równocześnie inspirację, by zbadać możliwość włączenia koncepcji „kształtowalności” do ontologii opierającej się na rozwiązaniach Heideggera. Byłby to wymiar bycia odnoszący się do kształtowania i bycia kształtowanymi przez inne byty, ulokowany na styku czasowości i światowości. Pozwala to pokazać, że bycie, rozumiane jako odsłanianie się swoistości poszczególnych bytów, może być odkryte również w zmianach będących wynikiem ich wzajemnego oddziaływania.

Słowa kluczowe: Heidegger, Arystoteles, wymiary bycia, zmiany, oddziaływanie

\section{Shapeability - Aristotelian Affectivity and the Missing Dimension of Being in Heidegger}

\section{Summary}

Heidegger's ontology, uncovering the multidimensionality of the phenomenon of being, seems to overlook an essential dimension of it. This gap pertains to the omission of the mutual affecting of beings, which leaves traces in beings. In identifying it, I draw upon Aristotle's concept of affecting/being affected (On Generation and Corruption, Book I), which seeks to explain the origin of alteration in beings. Referring to the Aristotelian juxtaposition of action-passion serves, however, to illustrate the above omission and is an inspiration to explore the possibility of incorporating the concept of 'shapeability' into the framework of Heidegger's ontology. This dimension of being's disclosure, located at the junction of timeliness and worldliness, will be related to shaping and being shaped by other beings. I shall show how being, understood as revealing a given being's specificity, can be disclosed in changes resulting from the inevitable mutual changing of beings.

Keywords: Heidegger, Aristotle, dimensions of being, changes, affectivity 